\title{
GnRH-I and GnRH-II-Induced Calcium Signaling and Hormone Secretion in Neonatal Rat Gonadotrophs
}

\author{
A. BALÍK, M. JINDŘICHOVÁ, S. BHATTACHARYYA, H. ZEMKOVÁ \\ Institute of Physiology Academy of Sciences of the Czech Republic, Prague, Czech Republic
}

Received June 25, 2008

Accepted August 4, 2008

On-line November 4, 2008

\section{Summary}

Two forms of gonadotropin-releasing hormone (GnRH), GnRH-I and GnRH-II, are commonly present in mammals. The main hormone controlling reproduction is GnRH-I acting through its receptor (GnRHR-I), whereas the function of GnRH-II is unknown. In primates, it has been suggested that $\mathrm{GnRH}-\mathrm{II}$ is a specific agonist for the structurally distinct GnRHR-II. Here we compared effects of GnRH-I and GnRH-II on intracellular calcium and gonadotropin hormone release in neonatal rat gonadotrophs in vitro and the dependence of agonist actions on cyclic nucleotide levels. Both agonists elevated intracellular calcium and stimulated gonadotropin secretion in a concentration-dependent manner, with comparable peak amplitudes, but GnRH-I was three times more potent than GnRH-II. Antide, a specific GnRHRI antagonist, completely blocked the action of both agonists on gonadotropin release. Inhibition of adenylyl cyclase activity by melatonin and MDL significantly attenuated GnRH-I- and GnRHII-induced calcium signaling and gonadotropin release, whereas inhibition of soluble guanylyl cyclase activity was ineffective. GnRH-II also generated calcium oscillations in a fraction of gonadotrophs not expressing melatonin receptors. These results indicate that GnRH-I and GnRH-II act on the same GnRHR to stimulate gonadotropin release through intracellular calcium and cyclic nucleotide signaling, and that GnRH-II is less potent agonist for this receptor in neonatal rat gonadotrophs.

\section{Key words}

Gonadotropin-releasing hormone - GnRH-II • Melatonin • LH • $\mathrm{FSH} \bullet$ Neonatal Rats

\section{Corresponding author}

H. Zemková, Institute of Physiology AS CR, Vídeňská 1083, 14220 Prague 4, Czech Republic. Fax: +420 241062488.

E-mail: zemkova@biomed.cas.cz

\section{Introduction}

Reproductive functions in vertebrates are controlled by decapeptide GnRH (gonadotropin-releasing hormone), also known as LHRH (luteinizing hormonereleasing hormone). GnRH-I, originally isolated from ovine and porcine tissues (Matsuo et al. 1971, Amoss et al. 1971), is synthesized by hypothalamic GnRH neurons of all mammalian species, and is secreted in a pulsatile manner into the hypophyseal portal system (Knobil 1988). GnRH-I governs reproductive functions by regulating the synthesis, glycosylation, and release of LH (luteinizing hormone) and FSH (follicle stimulating hormone) in anterior pituitary gonadotrophs, leading to stimulation of gonadal steroidogenesis and gametogenesis (Millar et al. 2004). GnRH-I binds with high affinity to gonadotropin-releasing hormone receptor (GnRHR), a plasma membrane receptor that belongs to the rhodopsin-like family of seven transmembrane domain receptors (Reinhart et al. 1992). The activated GnRHR-I couples to the pertussis toxin-insensitive $G_{\mathrm{q} / 11}$ proteins that stimulate phospholipase $C \beta$, an enzyme responsible for the generation of inositol-1,4,5trisphosphate $\left(\mathrm{IP}_{3}\right)$ and diacyglycerol, and for the $\mathrm{IP}_{3^{-}}$ dependent oscillatory elevations in cytosolic free calcium concentrations $\left(\left[\mathrm{Ca}^{2+}\right]_{\mathrm{i}}\right.$ ) (Hille et al. 1994, Stojilkovic et al. 1994). The GnRHR-I also couples to the cholera toxin-sensitive $G_{s}$ and/or pertussis toxin-sensitive $G_{i / o}$ proteins, depending on the cell type expressing GnRHR-I and duration of agonist application (Krsmanovic et al. 2003). The functional significance of modulation of adenylyl cyclase activity by GnRHR-I in pituitary gonadotrophs has not been studied.

Other forms of GnRHs are also present in 
individual species of most vertebrates; 16 structural variants or GnRH ligands have been isolated so far (King and Millar 1992, Parhar 2002, Somoza et al. 2002). All decapeptides are sharing identical residues at $1,4,9$, and 10 positions. Among these GnRHs, a form originally isolated from chicken brain (chicken GnRH, here termed GnRH-II) was found to be the most ubiquitous GnRH peptide with unknown function, commonly present in all vertebrates from fish to human (Somoza et al. 2002). The GnRH-I (pGlu-His-Trp-Ser-Tyr-Gly-Leu-Arg-Pro-Gly$\mathrm{NH}_{2}$ ) and GnRH-II (pGlu-His-Trp-Ser-His-Gly-Trp-TyrPro-Gly- $\mathrm{NH}_{2}$ ) peptides differ in three amino acids. GnRH-II is expressed in several regions of the central and peripheral nervous systems and in non-neural tissues (White et al. 1998), indicating that it might act as a neuromodulator, in addition to possible roles in the control of reproductive function (Millar 2003). Both GnRH-I and GnRH-II peptides stimulate steroidogenesis, inhibit cell proliferation, and may play a role in ovarian tumor growth (Kang et al. 2003). In the human pituitary stalk and the mouse median eminence, GnRH-II is present together with GnRH-I, as well as in the pituitary tissues of several teleost fish (Millar 2003). The GnRHs are not co-localized in the same cells and it has been hypothesized that these peptides may differentially regulate $\mathrm{LH}$ and FSH secretion and exert their effects simultaneously (Yu et al. 1997, Bosma et al. 2000, Yu et al. 2000).

Specific receptor for GnRH-II (GnRHR-II) was first described in lower vertebrates, then it was reported in primates (Millar et al. 2001, Neill et al. 2001, Parhar et al. 2005). Cloning of GnRHR-II from Marmoset monkey cDNA showed that this receptor has only $41 \%$ amino acid identity with the GnRHR-I and has a C-terminal tail, in contrast to GnRHR-I. Consequently, it undergoes desensitization and internalization. PCR and immunocytochemistry also showed that the GnRHR-II is expressed ubiquitously in human tissues (Grundker et al. 2002), including brain, pituitary and reproductive tissues (Millar et al. 2001, Neill et al. 2001), couples to $\mathrm{G}_{\mathrm{q} / 11}$ proteins (White et al. 1998) and stimulates the production of $\mathrm{IP}_{3}$ when activated by its specific agonist GnRH-II (Millar et al. 2001). So far, there is no evidence for the presence of this receptor subtype in rats and the stimulatory action of GnRH-II on $\mathrm{IP}_{3}$ production and gonadotropin release appears to be mediated by GnRHR-I (Okada et al. 2003, Mongiat et al. 2004).

Here we compared effects of GnRH-I and GnRH-II on calcium signaling and gonadotropin release in rat neonatal pituitary gonadotrophs. Like gonadotrophs from prepubertal, peripubertal and adult animals, neonatal gonadotrophs express functional GnRHR-I. A larger fraction of neonatal gonadotrophs also expresses high levels of melatonin MT1 and MT2 receptors, which operate through $\mathrm{G}_{\mathrm{i} / \mathrm{o}}$ signaling pathway (Vaněček 1988) (Balík et al. 2004). Our results are consistent with the data of Mongiat et al. (2004), indicating that the stimulatory action of GnRH-II on gonadotropin release is mediated by GnRHR-I and inhibited by melatonin, but that this agonist is not equipotent as GnRH-I in triggering the secretion. We also show that in neonatal gonadotrophs cAMP signaling pathway significantly contributes to agonist control of gonadotropin secretion, probably serving as an amplifier of calcium-mediated exocytosis.

\section{Methods}

\section{Chemicals}

GnRH-I, GnRH II and Antide were obtained from Bachem (Peninsula Laboratories, Belmont, CA, USA); Pluronic F-127 and Fura-2AM from Molecular Probes (Eugene, OR, USA); MDL-12,330A (hydrochloride [cis-N-(2-phenylcyclopentyl)azacyclotridec-1-en-2-amine.HCl]) from Alexis (Lausen, Switzerland); ODQ $\quad(1 \mathrm{H}-[1,2,4]$ oxadiazolo[4,3-a] quinoxalin-1-one) from Tocris (Bristol, UK); melatonin and other chemicals from Sigma (St. Louis, MO, USA).

\section{Cell preparation and culture}

Wistar rats (4-6 days old) were used for cell preparation. Animals were decapitated, anterior pituitaries were extracted, and cells were dissociated by papain as described previously (Mandler et al. 1990). Purification of gonadotrophs was done using discontinuous BSA gradient, plated on glass coverslips and cultured in medium 199 containing Earle's salts, sodium bicarbonate, $10 \%$ heat-inactivated horse serum, and penicillin $(100 \mathrm{U} / \mathrm{ml})$ and streptomycin $(100 \mu \mathrm{g} / \mathrm{ml})$ in $95 \%$ air $/ 5 \% \mathrm{CO}_{2}$ at $37{ }^{\circ} \mathrm{C}$ overnight. Experiments were approved by the Animal Care and Use Committee of the Academy of Sciences of the Czech Republic.

\section{Radioimmunoassay}

LH and FSH release was determined by radioimmunoassay using antiserum and standards (RP-3) provided from the National Pituitary Agency and Dr. AF Parlow (Harbor-UCLA Medical Center, Torrance, CA). 
Pituitary cells were cultured in 24-well plates. On day 2 , cells were subjected in sixtuplicates to the different experimental maneuvers. After $3 \mathrm{~h}$, supernatants were collected and LH or FSH concentration was measured by radioimmunoassay (Vaněček and Klein 1995). The secretion was expressed as the amount of hormone released by $15 \times 10^{4}$ cells (ng/well), or as normalized mean \pm S.E.M. values. Inter- and intraassay coefficients of variation were $8.5 \%$ and $2.4 \%$, respectively; the sensitivity of the assay was $20 \mathrm{pg}$.

\section{Calcium measurement}

Changes in the intracellular calcium concentration $\left(\left[\mathrm{Ca}^{2+}\right]_{\mathrm{i}}\right)$ were measured in single pituitary cells incubated in M199 and loaded with $2 \mu \mathrm{M}$ Fura-2 AM (Molecular Probes, Eugene, OR) at $37{ }^{\circ} \mathrm{C}$ for $60 \mathrm{~min}$. Coverslips with cells were then washed with KrebsRinger buffer and mounted on the stage of an upright microscope Olympus BX50WI-IR with fluorescence attachment (Melville, NY, USA) and METAFLUOR Imaging Software (Visitron Systems, Germany). During recording, dishes with cell cultures were continuously perfused with an extracellular solution of the following composition (in $\mathrm{mM}$ ): $160 \mathrm{NaCl}, 2.5 \mathrm{KCl}, 1 \mathrm{MgCl}_{2}$, $1 \mathrm{CaCl}_{2}, 10$ glucose and $10 \mathrm{~N}$-2-hydroxyethylpiperazine$\mathrm{N}$-2-ethanesulfonic acid (HEPES); $\mathrm{pH}$ adjusted with $1 \mathrm{M}$ $\mathrm{NaOH}$ to 7.3. Medium and drugs were applied using a fast gravity driven micro perfusion system consisting of ten glass tubes each approximately $400 \mu \mathrm{m}$ in diameter with common outlet. Solution application was controlled by microcomputer and miniature teflon solenoid valves. Complete exchange of the solution around recorded cells required less than $500 \mathrm{~ms}$. Cells were examined under an $\mathrm{x} 40$ water immersion objective during exposure to alternating $340 \mathrm{~nm}$ and $380 \mathrm{~nm}$ light beams, and the intensity of light emission at $520 \mathrm{~nm}$ was measured. The ratio of light intensities, $\mathrm{F}_{340} / \mathrm{F}_{380}$, which reflects the changes in $\mathrm{Ca}^{2+}$ concentration, was followed in several single cells at the rate of one point per second.

\section{Results}

Gonadotropin secretion in neonatal pituitary cells is more sensitive to GnRH-I than GnRH-II

LH release was measured in mixed population of pituitary cells, which have been cultured for one day. Samples were collected after $3 \mathrm{~h}$ incubation with different concentrations of agonists and analyzed for their LH and FSH contents. Basal LH secretion in vitro was low and
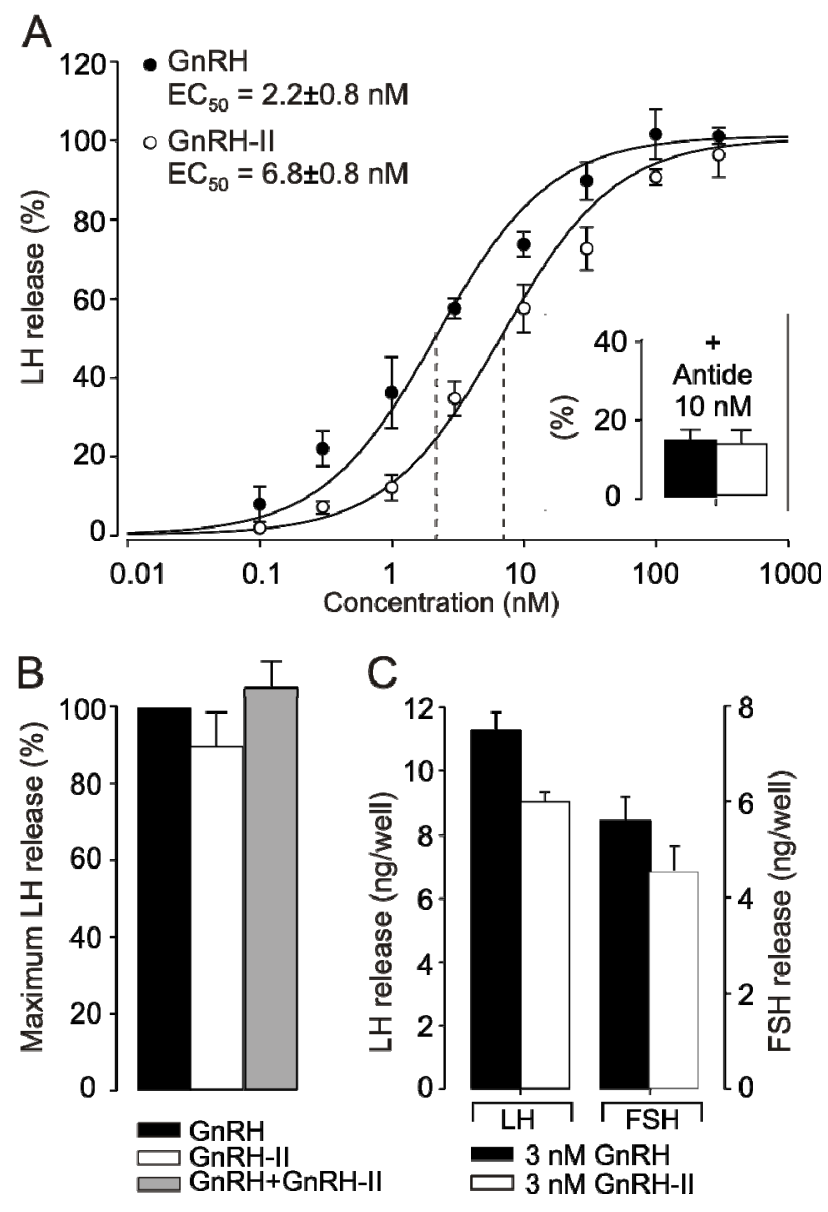

Fig. 1. LH and FSH release stimulated by GnRH-I and GnRH-II in primary culture of neonatal pituitary cells. A. The release of $\mathrm{LH}$ was stimulated by both GnRH-I (here and in all figures marked as $\mathrm{GnRH}$ ) and GnRH-II in a dose-dependent manner. The GnRH-II dose-response curve (open circles) was shifted to the right when compared to GnRH-I dose-response curve (closed circles). Concentrations inducing half-maximal effects ( $\mathrm{EC}_{50}$ values) are shown above traces. Both GnRH-I- and GnRH-II-induced LHrelease, stimulated by $\mathrm{EC}_{50}$ concentrations, was inhibited by specific inhibitor of GnRHR-I Antide (inset). B. Maximum LH release stimulated by GnRH-I (300 nM), GnRH-II (300 nM) and both GnRHs was comparable. C. The ratio of secretion of both hormones in response to GnRH-II and GnRH-I application was comparable.

was subtracted in measurements. Figure 1A shows concentration-response curves for GnRH-I and GnRH-IIstimulated LH release, which could be fitted by a sigmoid function. From fitted functions, done in 15 experiments, we calculated mean $\mathrm{EC}_{50}$ values: GnRH-I $2.2 \pm 0.8 \mathrm{nM}$ and GnRH-II $6.8 \pm 0.3 \mathrm{nM}$. Similar profiles of GnRH-I and GnRH-II-induced LH secretion was consistent with a hypothesis that GnRH-I and GnRH-II act on the same receptor in neonatal pituitary gonadotrophs, but with different potencies.

In accordance with this hypothesis, Antide in a concentration $(10 \mathrm{nM})$ that only blocks GnRHR-I, 


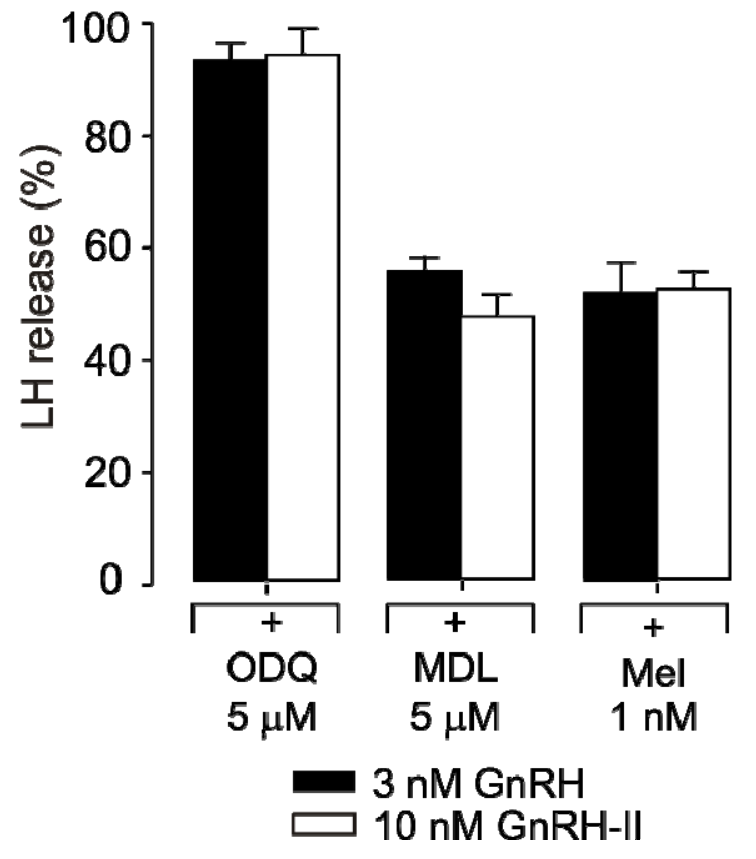

Fig. 2. The effect of adenylyl cyclase inhibitors on LH secretion stimulated by GnRH-I and GnRH-II. The GnRH-I- and GnRH-IIinduced LH release in primary culture of neonatal pituitary cells was inhibited by common adenylyl cyclase inhibitor MDL $(5 \mu \mathrm{M})$ and pineal hormone melatonin (Mel; $1 \mathrm{nM}$ ). The effect of inhibition of soluble guanylyl cyclase by ODQ $(5 \mu \mathrm{M})$ was insignificant in both cases.

inhibited LH release stimulated with both GnRHs by $82-85 \%$ (Fig. 1A, inset). Furthermore, there was no significant difference between the maximum amplitude values induced by $300 \mathrm{nM}$ GnRH-I, GnRH-II or mixture of both peptides, indicating that effects of both GnRHs were not additive (Fig. 1B). In five experiments, pituitary cells were stimulated with $3 \mathrm{nM}$ GnRH-I or $3 \mathrm{nM}$ GnRHII and LH and FSH secretion was measured. The secretion of both hormones in response to GnRH-II application was lower by about $20 \%$ as compared with GnRH-I, but the ratio of both values was the same (Fig. 1C).

Inhibition of adenylyl cyclase attenuates GnRH-induced LH release

Because agonist stimulation of GnRHR-I involves activation of adenylyl cyclase (AC), and soluble quanylyl cyclase (sGC) (Vaněček and Vollrath 1989), next we examined effects of MDL $(5 \mu \mathrm{M})$, a common inhibitor of ACs, and ODQ $(5 \mu \mathrm{M})$, a specific inhibitor of sGC (Kostic et al. 2004, Gonzalez-Iglesias et al. 2006). Cultures were incubated for $3 \mathrm{~h}$ with agonists $(3 \mathrm{nM}$ GnRH-I and $10 \mathrm{nM}$ GnRH-II) in the presence and absence of drugs (Fig. 2). We found only a slight reduction of both agonist-induced LH release by ODQ

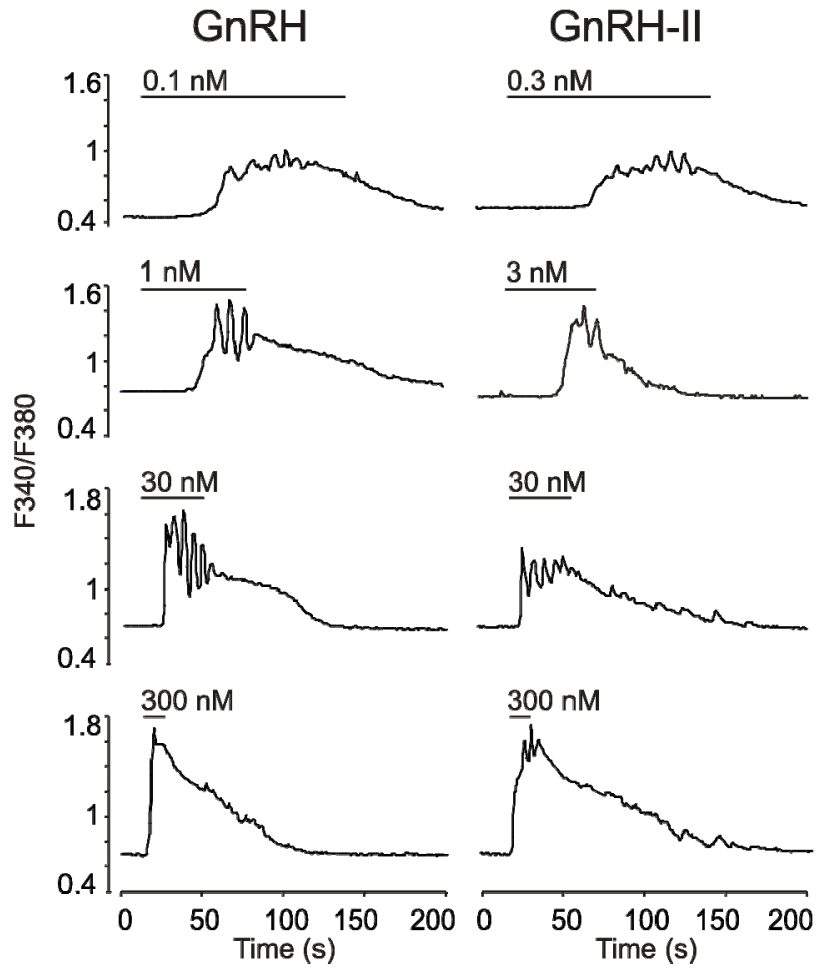

Fig. 3. The effect of GnRH-II on calcium oscillations in neonatal gonadotrophs. GnRH-II stimulated oscillatory increase in $\left[\mathrm{Ca}^{2+}\right]_{\mathrm{i}}$ in the same subpopulation of neonatal gonadotrophs, which also responded to $\mathrm{GnRH}-\mathrm{I}$, but the threshold concentration was different GnRH-I-induced calcium responses could be evoked at $0.1 \mathrm{nM}$ (left), whereas GnRH-II-induced oscillations started after stimulation with $0.3 \mathrm{nM}$ (right). Horizontal bars above traces indicate the time of agonist application.

(by $5 \%$ and $7 \%$ for GnRH-I and GnRH-II, respectively), indicating that cGMP signaling is not critical for GnRHsinduced gonadotropin release. In contrast, there was a significant inhibition of agonist-induced LH release by MDL (by $45 \%$ and $52 \%$, respectively). Melatonin (1 nM) inhibited GnRH-I and GnRH-II-stimulated LH release by $49 \%$ and $48 \%$, respectively. These results indicate that the secretory action of both agonists depends on the status of adenylyl cyclase activity.

\section{Single cell calcium response by GnRH-I and GnRH-II}

It is well established that GnRH-I acts on its $\mathrm{Ca}^{2+}$-mobilizing receptors in gonadotrophs, leading to oscillatory release of calcium from intracellular stores. In neonatal gonadotrophs, GnRH-I induced various types of $\mathrm{Ca}^{2+}$-oscillations and the oscillatory pattern of these responses differed considerably from cell to cell, but was very similar when the same cell was stimulated repeatedly with the same concentration of GnRH-I (Iida et al. 1991, Tomic et al. 1994, Zemková and Vaněček 2000). It is well established that calcium is the major intracellular signaling molecule mediating the action of 

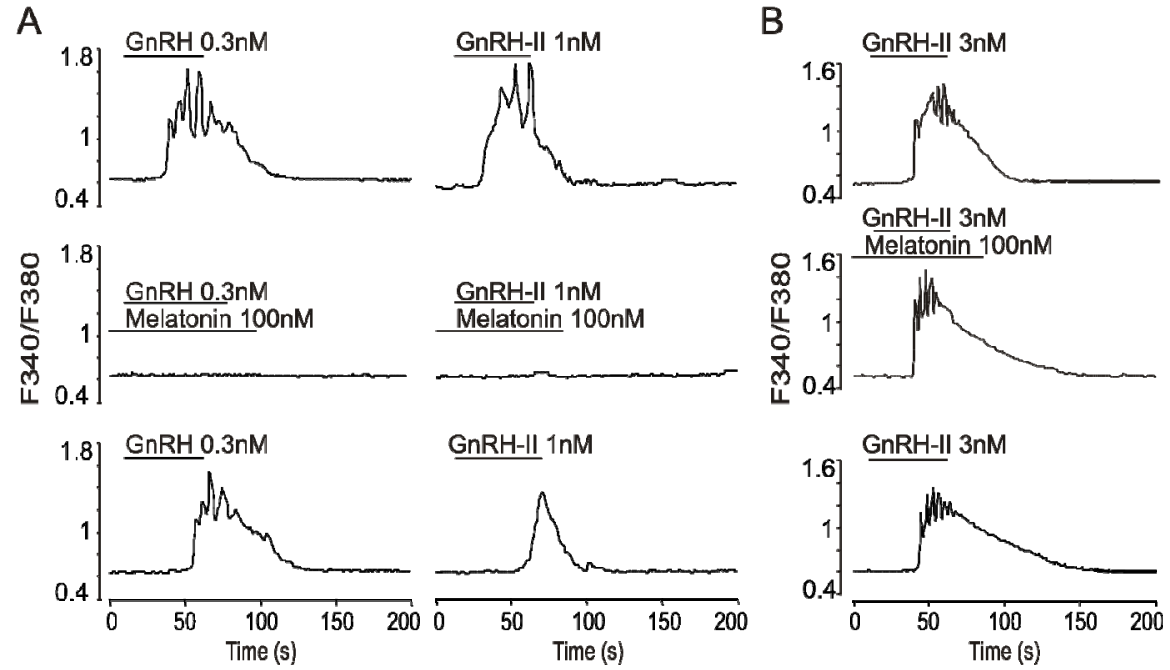

Fig. 4. Melatonin sensitivity of GnRH-I and $\mathrm{GnRH}-\mathrm{II}$-induced calcium responses. A. Melatonin inhibited $\mathrm{Ca}^{2+}$ oscillations evoked by both GnRH-I and GnRH-IIinduced in the same cell. Melatoninsensitive cells represent a subpopulation of neonatal gonadotrophs. B. GnRH-II also induced oscillations in melatonininsensitive gonadotrophs.
GnRH-I on gonadotropin release (Stojilkovic and Catt 1992, Tse and Hille 1992). Single-cell calcium measurements revealed that GnRH-II, like GnRH-I, increased $\left[\mathrm{Ca}^{2+}\right]_{\mathrm{i}}$ when applied for 5-120 s. An increase in GnRH-I concentration from 0.1 to $30 \mathrm{nM}$ also increased the frequency of superimposed oscillations and shortened the latency preceding the GnRH-I-induced response (Fig. 3, left) by the time of beginning of agonist application and onset of response, but had little effect on the maximum response. An increase in GnRH-I concentration above $100 \mathrm{nM}$ usually produces a transition from oscillatory to non-oscillatory spike response. The same pattern of calcium responses was observed when the cells were stimulated with increasing concentrations of GnRH-II (Fig. 3, right). However, the threshold concentration was higher for GnRH-II $(\sim 0.3 \mathrm{nM})$ as compared with that for GnRH-I $(\sim 0.1 \mathrm{nM})$.

Melatonin (1 nM), applied together with GnRH-I or GnTh-II, prolonged latency (not shown) or completely inhibited agonist-induced calcium responses when cells were stimulated with lower GnRH concentrations (Fig. 4A). However, both effects were observed only in $52 \%$ of neonatal gonadotrophs, which is in accordance with literature showing the expression of functional receptors in 40-70 \% of neonatal gonadotrophs (Vaněček and Klein 1992, Zemková and Vaněček 1997). Remaining cells were melatonin-insensitive, and these cells also responded to GnRH-II (Fig. 4B). At higher agonist concentrations, melatonin was ineffective (data not shown). These results indicate that melatonin inhibits GnRH-I and GnRH-II-induced gonadotropin release by inhibiting initiation of calcium signaling and in a calcium-dependent (Zemková and Vaněček 2000) and probably cAMP/protein kinase C-dependent manner.

\section{Discussion}

Here we show that GnRH-II has comparable effects as GnRH-I in pituitary cells from 4- to 6-day-old rats. Both agonists evoked comparable $\left[\mathrm{Ca}^{2+}\right]_{i}$ signals and secretory outputs in a dose-dependent manner, a finding consistent with a major role of calcium signals in controlling exocytosis of dense core vesicles in these cells (Hille et al. 1994). Three lines of evidence argue against the functional expression of GnRHR-II in neonatal gonadotrophs: 1) there was no difference in the maximum $\mathrm{LH}$ and FSH response when cells were stimulated with the supramaximal agonist concentrations (300 nM), 2) the action of two agonists was not additive, and 3) Antide inhibits GnRHR-I and GnRHR-II signaling with the $\mathrm{EC}_{50}$ concentrations of 1 and $10000 \mathrm{nM}$, respectively (Neill 2002). In our hands, the action of both agonists was abolished by $10 \mathrm{nM}$ of this GnRHR-Ispecific blocker.

We also found that the $\mathrm{EC}_{50}$ value for $\mathrm{GnRH}-\mathrm{II}$ was shifted about three times rightward compared to GnRH-I, which is consistent with heterologous activation of the GnRHR-I in neonatal rat pituitary. Theoretically, an activation of receptor with ligand of lower affinity could induce differences in receptor conformation changes and lower effect. In the case of $G$ proteincoupled receptors, the domain that determines agonist specificity does not affect interaction with $G$ protein on the intracellular side of the receptor (Colquhoun 1998). This could explain why maximum effect of stimulation with both GnRHs was identical. These results are in agreement with previous findings obtained in pituitary cells from adult monkey or rats (Okada et al. 2003) and from 15-day-old rats (Mongiat et al. 2004) showing that 
GnRH-II increases production of intracellular $\mathrm{IP}_{3}$ and gonadotropin secretion by activating GnRH-I receptors.

In vertebrates, including rats, GnRH-II is more widely distributed than GnRH-I, indicating that it might have several roles (Millar et al. 2001). However, gene for GnRHR-II could not be detected in peripubertal rats (Mongiat et al. 2004) and we have also failed to obtain direct evidence of mRNA transcript for GnRHR-II in total RNA from neonatal pituitary (Balík, unpublished). The findings that GnRH-II can activate GnRH-I receptor in neonatal rat pituitary, and that GnRH-II was a less effective stimulator of both LH and FSH secretion than was GnRH-I, support the idea that it may have main biological effects in non-reproductive functions in the rat.

Earlier studies have revealed that activation of melatonin receptors in pituitary cells leads to inhibition of cAMP production (Vanecek and Vollrath 1989). MDL, a broad adenylyl cyclase inhibitor, also down-regulates cAMP production in pituitary cells (Gonzalez-Iglesias et al. 2006). However, the role of cAMP in GnRH-induced gonadotropin secretion has not been clarified. Here we show that in neonatal gonadotrophs, the GnRH-I and GnRH-II-stimulated secretion of hormones is sensitive to both receptor- and non-receptor-mediated inhibition of adenylyl cyclase. The inhibitory action of melatonin and
MDL could be partially related to the control of voltagedependent $\mathrm{Ca}^{2+}$ channels and calcium entry, which is important for agonist-induced calcium signaling (Zemková and Vaněček 2000). This in turn affects gonadotropin secretion as demonstrated earlier (Stojilkovic and Catt 1995). However, melatonin was ineffective in blocking calcium signals stimulated with high doses of GnRH-I (Zemkova and Vanecek 2001) or GnRH-II (here, data not shown), indicating that it also inhibits secretion by calcium-independent mechanism. This is consistent with findings in other secretory anterior pituitary cells showing effects of cAMP, presumably through protein kinase $\mathrm{A}$, on exocytosis of dense core vesicles (Zorec et al. 1991).

\section{Conflict of Interest}

There is no conflict of interest.

\section{Acknowledgements}

This study was supported by the Grant Agency of the Czech Republic (305/07/0681) and the Internal Grant Agency of the Academy of Sciences IAA500110702, Research Project AVOZ 50110509), and the Centrum for Neuroscience (Research Project LC554). We thank Dr. Stanko S. Stojilkovic for helpful comments.

\section{References}

AMOSS M, BURGUS R, BLACKWELL R, VALE W, FELLOWS R, GUILLEMIN R: Purification, amino acid composition and N-terminus of the hypothalamic luteinizing hormone releasing factor (LRF) of ovine origin. Biochem Biophys Res Commun 44: 205-210, 1971.

BALÍK A, KRETSCHMANNOVÁ K, MAZNA P, SVOBODOVÁ I, ZEMKOVÁ H: Melatonin action in neonatal gonadotrophs. Physiol Res 53 (Suppl 1): S153-S166, 2004.

BOSMA PT, REBERS FE, DIJK W, WILLEMS PH, GOOS HJ, SCHULZ RW: Inhibitory and stimulatory interactions between endogenous gonadotropin-releasing hormones in the African catfish (Clarias gariepinus). Biol Reprod 62: 731-738, 2000.

COLQUHOUN D: Binding, gating, affinity and efficacy: the interpretation of structure-activity relationships for agonists and of the effects of mutating receptors. Br J Pharmacol 125: 924-947, 1998.

GONZALEZ-IGLESIAS AE, JIANG Y, TOMIC M, KRETSCHMANNOVA K, ANDRIC SA, ZEMKOVA H, STOJILKOVIC SS: Dependence of electrical activity and calcium influx-controlled prolactin release on adenylyl cyclase signaling pathway in pituitary lactotrophs. Mol Endocrinol 20: 2231-2246, 2006.

GRUNDKER C, GUNTHERT AR, MILLAR RP, EMONS G: Expression of gonadotropin-releasing hormone II (GnRH-II) receptor in human endometrial and ovarian cancer cells and effects of GnRH-II on tumor cell proliferation. J Clin Endocrinol Metab 87: 1427-1430, 2002.

HILLE B, TSE A, TSE FW, ALMERS W: Calcium oscillations and exocytosis in pituitary gonadotropes. Ann N Y Acad Sci 710: 261-270, 1994.

IIDA T, STOJILKOVIC SS, IZUMI S, CATT KJ: Spontaneous and agonist-induced calcium oscillations in pituitary gonadotrophs. Mol Endocrinol 5: 949-958, 1991. 
KANG SK, CHOI KC, YANG HS, LEUNG PC: Potential role of gonadotrophin-releasing hormone (GnRH)-I and GnRH-II in the ovary and ovarian cancer. Endocr Relat Cancer 10: 169-177, 2003.

KING JA, MILLAR RP: Evolution of gonadotropin-releasing hormones. Trends Endocrinol Metab 3: 339-346, 1992.

KNOBIL E: The neuroendocrine control of ovulation. Hum Reprod 3: 469-472, 1988.

KOSTIC TS, ANDRIC SA, STOJILKOVIC SS: Receptor-controlled phosphorylation of alpha 1 soluble guanylyl cyclase enhances nitric oxide-dependent cyclic guanosine 5'-monophosphate production in pituitary cells. $\mathrm{Mol}$ Endocrinol 18: 458-470, 2004.

KRSMANOVIC LZ, MORES N, NAVARRO CE, ARORA KK, CATT KJ: An agonist-induced switch in G protein coupling of the gonadotropin-releasing hormone receptor regulates pulsatile neuropeptide secretion. Proc Natl Acad Sci USA 100: 2969-2974, 2003.

MANDLER RN, SCHAFFNER AE, NOVOTNY EA, LANGE GD, SMITH SV, BARKER JL: Electrical and chemical excitability appear one week before birth in the embryonic rat spinal cord. Brain Res 522: 46-54, 1990.

MATSUO H, BABA Y, NAIR RM, ARIMURA A, SCHALLY AV: Structure of the porcine LH- and FSH-releasing hormone. I. The proposed amino acid sequence. Biochem Biophys Res Commun 43: 1334-1339, 1971.

MILLAR R, LOWE S, CONKLIN D, PAWSON A, MAUDSLEY S, TROSKIE B, OTT T, MILLAR M, LINCOLN G, SELLAR R, FAURHOLM B, SCOBIE G, KUESTNER R, TERASAWA E, KATZ A: A novel mammalian receptor for the evolutionarily conserved type II GnRH. Proc Natl Acad Sci USA 98: 9636-9641, 2001.

MILLAR RP: GnRH II and type II GnRH receptors. Trends Endocrinol Metab 14: 35-43, 2003.

MILLAR RP, LU ZL, PAWSON AJ, FLANAGAN CA, MORGAN K, MAUDSLEY SR: Gonadotropin-releasing hormone receptors. Endocr Rev 25: 235-275, 2004.

MONGIAT LA, LUX-LANTOS VA, LIBERTUN C: Evidence for different gonadotropin-releasing hormone response sites in rat ovarian and pituitary cells. Biol Reprod 71: 464-469, 2004.

NEILL JD: GnRH and GnRH receptor genes in the human genome. Endocrinology 143: 737-743, 2002.

NEILL JD, DUCK LW, SELLERS JC, MUSGROVE LC: A gonadotropin-releasing hormone (GnRH) receptor specific for GnRH II in primates. Biochem Biophys Res Commun 282: 1012-1018, 2001.

OKADA Y, MUROTA-KAWANO A, KAKAR SS, WINTERS SJ: Evidence that gonadotropin-releasing hormone $(\mathrm{GnRH})$ II stimulates luteinizing hormone and follicle-stimulating hormone secretion from monkey pituitary cultures by activating the GnRH I receptor. Biol Reprod 69: 1356-1361, 2003.

PARHAR IS: Cell migration and evolutionary significance of GnRH subtypes. Prog Brain Res 141: 3-17, 2002.

PARHAR IS, OGAWA S, SAKUMA Y: Three GnRH receptor types in laser-captured single cells of the cichlid pituitary display cellular and functional heterogeneity. Proc Natl Acad Sci USA 102: 2204-2209, 2005.

REINHART J, MERTZ LM, CATT KJ: Molecular cloning and expression of cDNA encoding the murine gonadotropin-releasing hormone receptor. J Biol Chem 267: 21281-21284, 1992.

SOMOZA GM, MIRANDA LA, STROBL-MAZZULLA P, GUILGUR LG: Gonadotropin-releasing hormone (GnRH): from fish to mammalian brains. Cell Mol Neurobiol 22: 589-609, 2002.

STOJILKOVIC SS, CATT KJ: Calcium oscillations in anterior pituitary cells. Endocr Rev 13: 256-280, 1992.

STOJILKOVIC SS, CATT KJ: Expression and signal transduction pathways of gonadotropin-releasing hormone receptors. Recent Prog Horm Res 50: 161-205, 1995.

STOJILKOVIC SS, TOMIC M, KUKULJAN M, CATT KJ: Control of calcium spiking frequency in pituitary gonadotrophs by a single-pool cytoplasmic oscillator. Mol Pharmacol 45: 1013-1021, 1994.

TOMIC M, CESNAJAJ M, CATT KJ, STOJILKOVIC SS: Developmental and physiological aspects of $\mathrm{Ca}^{2+}$ signaling in agonist-stimulated pituitary gonadotrophs. Endocrinology 135: 1762-1771, 1994.

TSE A, HILLE B: GnRH-induced $\mathrm{Ca}^{2+}$ oscillations and rhythmic hyperpolarizations of pituitary gonadotropes. Science 255: 462-464, 1992.

VANĚČEK J: Melatonin binding sites. J Neurochem 51: 1436-1440, 1988.

VANĚČEK J: Inhibitory effect of melatonin on GnRH-induced LH release. Rev Reprod 4: 67-72, 1999.

VANĚČEK J, VOLLRATH L: Melatonin inhibits cyclic AMP and cyclic GMP accumulation in the rat pituitary. Brain Res 505: 157-159, 1989.

VANĚČEK J, KLEIN DC: Melatonin inhibits gonadotropin-releasing hormone-induced elevation of intracellular $\mathrm{Ca}^{2+}$ in neonatal rat pituitary cells. Endocrinology 130: 701-707, 1992. 
VANĚČEK J, KLEIN DC: Mechanism of melatonin signal transduction in the neonatal rat pituitary. Neurochem Int 27: 273-278, 1995.

WHITE RB, EISEN JA, KASTEN TL, FERNALD RD: Second gene for gonadotropin-releasing hormone in humans. Proc Natl Acad Sci USA 95: 305-309., 1998.

YU WH, KARANTH S, WALCZEWSKA A, SOWER SA, MCCANN SM: A hypothalamic follicle-stimulating hormone-releasing decapeptide in the rat. Proc Natl Acad Sci USA 94: 9499-9503, 1997.

YU WH, KARANTH S, SOWER SA, PARLOW AF, MCCANN SM: The similarity of FSH-releasing factor to lamprey gonadotropin- releasing hormone III (1-GnRH-III). Proc Soc Exp Biol Med 224: 87-92., 2000.

ZEMKOVÁ H, VANĚČEK J: Inhibitory effect of melatonin on gonadotropin-releasing hormone-induced $\mathrm{Ca}^{2+}$ oscillations in pituitary cells of newborn rats. Neuroendocrinology 65: 276-283, 1997.

ZEMKOVÁ H, VANĚČEK J: Differences in gonadotropin-releasing hormone-induced calcium signaling between melatonin-sensitive and melatonin-insensitive neonatal rat gonadotrophs. Endocrinology 141: 1017-1026, 2000.

ZEMKOVÁ H, VANĚČEK J: Dual effect of melatonin on gonadotropin-releasing hormone-induced $\mathrm{Ca}^{2+}$ signaling in neonatal rat gonadotropes. Neuroendocrinology 74: 262-269, 2001.

ZOREC R, SIKDAR SK, MASON WT: Increased cytosolic calcium stimulates exocytosis in bovine lactotrophs. Direct evidence from changes in membrane capacitance. J Gen Physiol 97: 473-497, 1991. 